\title{
METODY OBLICZEŃ EFEKTÓW DRUGIEGO RZĘDU - UWAGI I PORÓWNANIA
}

\begin{abstract}
W przypadku, gdy wymiaruje się smukłe słupy, może zachodzić konieczność uwzględnienia w obliczeniach statycznych efektów drugiego rzędu. Oznacza to, że siły wyznaczone przy założeniu zesztywnienia konstrukcji należy powiększyć o wartości wynikające z przemieszczeń. W praktyce sprowadza się to do wyznaczenia przyrostu momentu lub mimośrodu działania siły. Inżynier projektant ma do dyspozycji trzy metody obliczeniowe i staje przed problemem wyboru i oceny zastosowanej metody. W pracy omówiono ogólnie te metody i przedstawiono porównania otrzymywanych wyników. Okazało się, że w wielu sytuacjach różnice pomiędzy rezultatami są znaczne. Ogólnie można stwierdzić, że zastosowanie metody nominalnej sztywności prowadzi do przyjmowania znacząco większych wartości przyrostów momentu. Szczególnie ma to miejsce, gdy smukłość słupa jest duża i towarzyszy temu wysokie wytężenie betonu w przekroju. Do podobnych konkluzji dochodzi się uwzględniając wpływ pełzania na efekty drugiego rzędu.
\end{abstract}

Słowa kluczowe: efekty drugiego rzędu, nominalna krzywizna, nominalna sztywność, metoda ogólna, porównania wyników

\section{Wprowadzenie}

W sytuacji, gdy projektuje się budynki, w których architekci stosują smukłe słupy, znaczenia nabierają efekty drugiego rzędu. Oznacza to, że w analizie statycznej oraz wymiarowaniu należy uwzględniać wpływ przemieszczeń na wartości sił wewnętrznych. Norma [1] dopuszcza trzy sposoby obliczeń - metodę ogólną, metodę nominalnej sztywności oraz metodę nominalnej krzywizny. Opis metody ogólnej podany $\mathrm{w}$ normie sprowadza się jedynie do przedstawienia ogólnych wymagań i zaleceń. Projektowanie z jej wykorzystaniem jest tak naprawdę każdorazowo autorskim opracowaniem. Metoda nominalnej sztywności i nominalnej krzywizny są traktowane w normie jako praktycznie równorzędne metody przybliżone. W części krajów nie ma takiego wyboru a w MC2010 [2] jako jedyna opisana jest metoda nominalnej krzywizny.

\footnotetext{
${ }^{1}$ Janusz Pędziwiatr, Politechnika Wrocławska, Wydział Budownictwa Lądowego i Wodnego, Katedra Konstrukcji Betonowych, ul. Wybrzeże Wyspiańskiego 27, 50-370 Wrocław; janusz.pedziwiatr@pwr.edu.pl
} 
Sam opis tych metod jest dosyć ogólny i pozostawia czytelnikowi sporo wątpliwości. W zasadzie w Polsce $\mathrm{w}$ miarę szczegółowy opis podstaw tych metod i ich źródeł można znaleźć w [3]. Nawet jednak tam nie przedstawiono w sposób bezpośredni informacji istotnych dla bardziej wnikliwego inżyniera projektanta.

W artykule postarano się o częściowe wypełnienie tych luk a w szczególności pokazanie różnic w otrzymywanych z tych metod wyników oraz źródeł tych rozbieżności.

\section{Metody obliczeń}

\subsection{Metoda ogólna}

Istotą metody jest jak najściślejsze połączenie zależności geometrycznych przemieszczenia i krzywizny $\mathrm{z}$ wartościami statycznymi - momentem zginającym i siłą osiową. Oznacza to, że należy spełnić warunki wynikające z równania różniczkowego odkształconej osi pręta przy uwzględnieniu aktualnych wartości odkształceń w przekroju tego słupa. Norma zaleca przy tym, aby uwzględniać wpływ takich zjawisk jak pełzanie i zarysowanie.

W praktyce jest to procedura mocno skomplikowana. Bardziej szczegółowe wytyczne dotyczące sposobu postępowania można znaleźć w [3] oraz [4]. Projektowanie z wykorzystaniem tej metody wymaga każdorazowo sporządzenia dla określonej wartości siły osiowej $N_{E d}$, stopnia zbrojenia, geometrii przekroju itp. zależności pomiędzy krzywizną a momentem zginającym. Przykład takich krzywych pokazano na rys. 1. Linią ciągłą zaznaczono zależność dla $n_{E d}=0$ (czyste zginanie) a przerywaną dla $n_{E d}=0.2$. Gdy rośnie wartość $n_{E d}$, to zaczyna się obserwować znaczący przyrost sztywności.

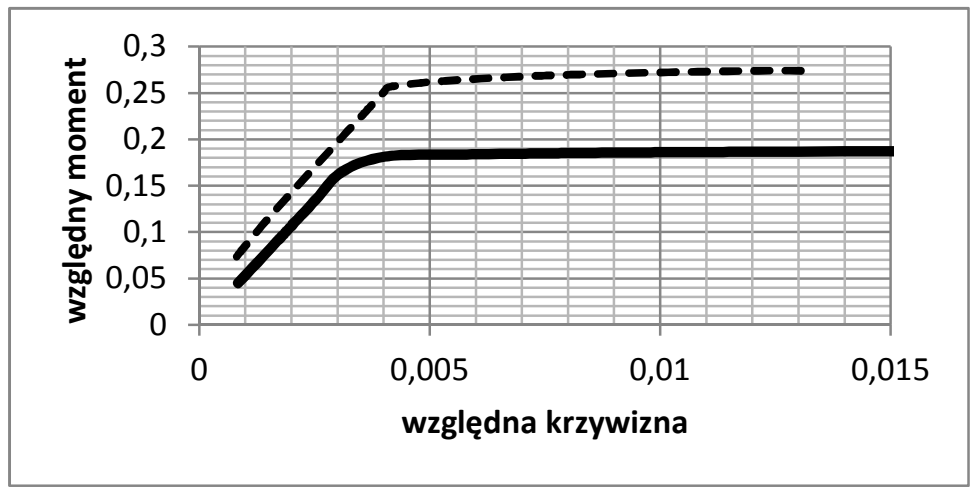

Rys. 1. Typowy wykres zależności względny moment-względna krzywizna dla $n_{E d}=0$ i $n_{E d}=0.2$ dla sumarycznego stopnia zbrojenia $2 \%$

Fig. 1.Typical relative moment-relative curvature diagram for constant axial load $n_{E d}=0$ i $n_{E d}=0.2$ and a steel ratio $2 \%$ 
W praktyce procedura postępowania polega na wyborze w konstrukcji słupa kilku punktów, w których sprawdzane są warunki równowagi i zgodności odkształceń oraz zależności pomiędzy nimi. Istotą metody jest proces iteracyjny i w konsekwencji analiza numeryczna analogiczna do metody różnic skończonych, gdzie równania różniczkowe zastępuje się równaniami różnicowymi.

\subsection{Metoda nominalnej sztywności}

Istotą tej metody jest założenie, że efekty drugiego rzędu można oszacować opisując je jako szereg kolejnych przyrostów mimośrodu działania siły i towarzyszące temu przyrosty momentu zginającego. Ostateczną wartością mimośrodu jest suma tego ciągu a kryterium jego zbieżności jest warunek, że $N_{E d} / N_{B}<1$. Stosuje się przy tym dodatkowe współczynniki, gdyż w istocie ciąg ten nie jest ciągiem ściśle geometrycznym - szczególnie gdy podparcia nie są przegubowe. Wzór zamieszczony w normie jest praktycznie tożsamy z zależnościami prezentowanymi w [5].

Bezwymiarowy przyrost momentu określa zależność:

$$
\delta=\frac{\beta}{\frac{N_{E d}}{N_{B}}-1}
$$

gdzie: $N_{B}=\frac{\pi^{2} E I}{l_{0}^{2}}-$ siła wyboczeniowa (krytyczna),

$\beta$ - współczynnik zależny od przebiegu momentów w słupie

Występująca w tych wzorach sztywność $E I$ jest sztywnością nominalną, którą można zapisać $\mathrm{w}$ odniesieniu do przekroju prostokątnego symetrycznie zbrojonego w następujący sposób:

$$
E I=\frac{b d^{3}}{12} E_{c m}\left[\frac{K_{c}}{1.2}(1+\alpha)^{3}+6 \alpha_{e} \rho(1-\alpha)^{2}\right]
$$

gdzie: $\alpha=a / d$

$\alpha_{e}=E_{s} / E_{c m}$ a pozostałe oznaczenia są zgodne z normą.

Po wstawieniu (2) do (1) otrzymuje się:

$$
\delta=\frac{\beta}{\frac{\pi^{2}}{\lambda^{2}} \frac{E_{c m}}{f_{c d} n_{E d}} \cdot \frac{\left[\frac{K_{c}}{1.2}(1+\alpha)^{3}+6 \alpha_{e} \rho(1-\alpha)^{2}\right]\left(1+\alpha+2 \rho \alpha_{e}\right)}{\left((1+\alpha)^{3}+6 \rho(1-\alpha)^{2} \alpha_{e}\right)}-1}
$$

gdzie: $n_{E d}=N_{E d} / f_{c d} b d$ - względna wartość siły osiowej. 
Wzór określający nominalną sztywność jest formułą empiryczną, w której istotne znaczenie ma współczynnik $K_{c}$ określony następującym wzorem:

$$
K_{c}=\frac{\sqrt{\frac{f_{c k}}{20}} n_{E d} \frac{\lambda}{170}}{1+\varphi_{e f}} \leq 0.2 \frac{\sqrt{\frac{f_{c k}}{20}}}{1+\varphi_{e f}}
$$

Występujące tu ograniczenie (dla dużych smukłości i sił) ma istotny wpływ na otrzymywane rezultaty.

\subsection{Metoda nominalnej krzywizny}

Metoda ta określana jest często jako addytywna, gdyż jej istota sprowadza się do zwiększenia początkowej wartości momentu o iloczyn wartości siły i dodatkowego ugięcia $e_{2}$ wynikającego z krzywizny pręta. Zakłada się przy tym, że krzywizna ta odpowiada sytuacji, w której w obu stalach osiągnięty został poziom odkształceń odpowiadający uplastycznieniu $\varepsilon_{s}=\varepsilon_{y d}=f_{y d} / E_{s} \mathrm{i}$ stosunek $a / d \approx 0.1$. Sytuacja taka występuje, gdy $n_{E d}=n_{b a l}$, to znaczy, jeżeli wartość siły odpowiada maksymalnemu momentowi granicznemu. Warto przy tym zauważyć, że norma zaleca przyjmować $n_{\text {bal }}=0.4$, chociaż dla betonów klasy nie większej niż C50/60 - dosyć powszechnie stosowanych, powinno to być $n_{b a l}=0.5$. Ostateczna postać wzoru na ugięcie $e_{2}$, uwzględniająca wartość siły $n_{E d}$ oraz efekty pełzania ma postać:

$$
e_{2}=\frac{\varepsilon_{y d}}{0.45 d} \frac{l_{0}^{2}}{c} \frac{n_{u}-n_{E d}}{n_{u}-n_{b a l}}\left[1+\varphi_{e f}\left(0.35+\frac{f_{c k}}{200}-\frac{\lambda}{150}\right)\right]
$$

Wyrażenie $\mathrm{w}$ nawiasie uwzględnia efekty pełzania ustalone empirycznie a $n_{u}$ jest względną wartością maksymalnej siły, którą może przenosić osiowo ściskany przekrój.

W celu porównywania obu metod wygodnie jest przedstawić normowy wzór w poniższej postaci

$$
M_{E d}=M_{0 E d}+N_{E d} e_{2}=N_{E d} e_{0}+N_{E d} e_{2}=N_{E d} e_{0}\left(1+\frac{e_{2}}{e_{0}}\right)
$$

Przyrost momentu opisuje więc zależność

$$
\delta=\frac{\varepsilon_{y d}}{0.45 e_{0} d} \frac{l_{0}^{2}}{c} \frac{n_{u}-n_{E d}}{n_{u}-n_{b a l}}\left[1+\varphi_{e f}\left(0.35+\frac{f_{c k}}{200}-\frac{\lambda}{150}\right)\right]
$$




\section{Porównania wyników obliczeń}

\subsection{Obciążenia doraźne}

Porównania wyników obu przybliżonych metod prowadzono w układzie współrzędnych bezwymiarowych, co umożliwiło analizy w ogólnej postaci. W pierwszej kolejności ograniczono się do efektów doraźnych, przyjmując $\varphi_{e f}=0$. Szczegółowe obliczenia wykonano dla betonu C30/37 stali ,500” ograniczając się do przekroju prostokątnego i $a / d=0.1$. Zmiennymi parametrami był stopień zbrojenia (zbrojenie symetryczne) oraz smukłość. Na rys. 2. pokazano przyrosty momentów obliczone metodą nominalnej krzywizny przy stopniu zbrojenia $\rho_{1}=\rho_{2}=1 \%$. Krzywą początkową, będącą krzywą graniczną, zaznaczono linią przerywaną. Widać, że ze wzrostem smukłości wartości momentów regularnie wzrastają. Zgodnie z intuicyjnymi oczekiwaniami największe względne przyrosty mają miejsce w sytuacji, gdy zdecydowana większość przekroju jest już ściskana. Gdy $\lambda=40$, maksymalny przyrost momentu wynosi $27 \%$, a dla kolejnych wartości $\lambda$ - odpowiednio 42 i $61 \%$. Inaczej sytuacja przedstawia się, gdy dokona się analizy efektów drugiego rzędu korzystając z metody nominalnej sztywności. Zostały one pokazane na rys. 3. Regularny kształt krzywych występuje jedynie do poziomu $\lambda=40$. Przy większych wartościach smukłości wyraźny jest znaczący przyrost momentów. Dotyczy on sytuacji, gdy w przekroju dominuje ściskanie. Bardzo charakterystyczne jest to, że im większy jest zasięg strefy ściskanej, tym przyrosty momentów są większe. Przekłada się to bezpośrednio na różnice w wynikach pomiędzy oba metodami.

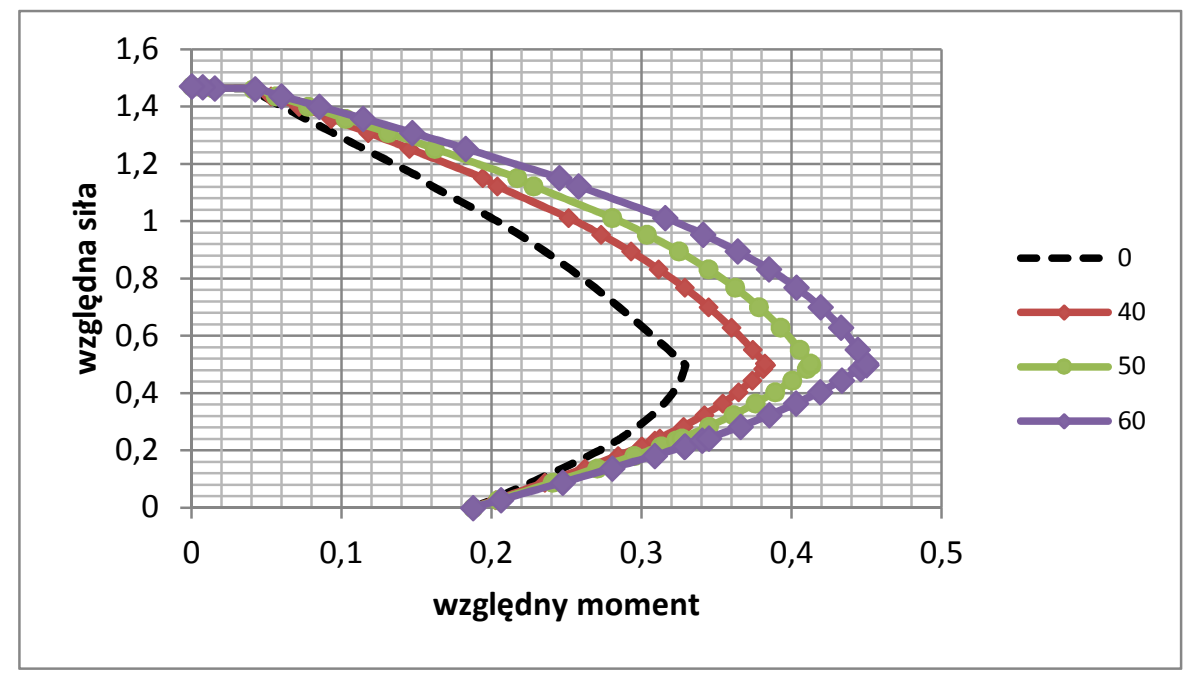

Rys. 2. Efekty przyrostu momentu w funkcji smukłości słupa - metoda nominalnej krzywizny

Fig. 2. The effects of bonding moment increasing up to slenderness - the method of nominal curvature 


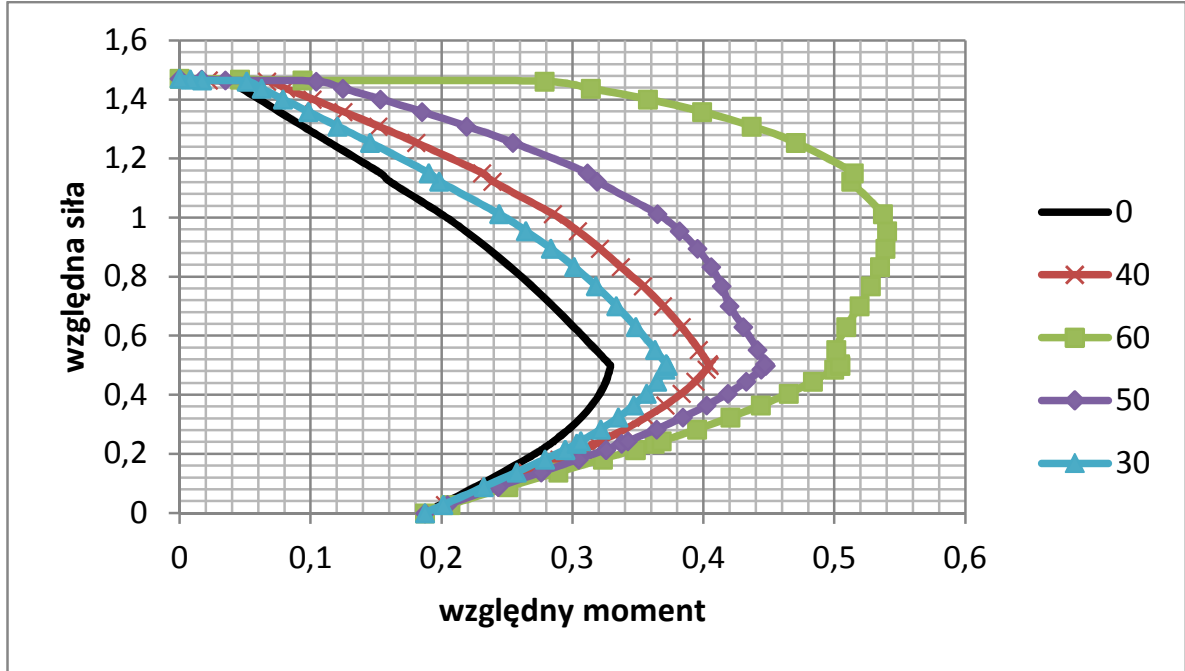

Rys. 3. Efekty przyrostu momentu w funkcji smukłości słupa - metoda nominalnej sztywności

Fig. 3. The effects of bonding moment increasing up to slenderness - the method of nominal stiffness

Wybrane rezultaty tych porównań przedstawiono $\mathrm{w}$ tab. 1. We wszystkich przypadkach większe wartości otrzymuje się korzystając z metody nominalnej sztywności. Przy niewielkich wartościach smukłości $(\lambda=30)$ różnice w otrzymanych wynikach są nieznaczne. Gdy smukłość jest większa $(\lambda=50)$, poważniejsze różnice występują począwszy od $n_{E d}=0.895$. Przy jeszcze większych smukłościach zjawisko to można zaobserwować już począwszy od $n_{E d}=0.364$. Dla większych wartości względnej siły osiowej $n_{E d}$ różnice stają się już bardzo znaczne i sięgają $100 \%$. Ta ostatnia wartość dotyczy sytuacji, gdy cały przekrój jest ściskany.

Przedstawione tu różnice mają swoje źródło w strukturze zależności zastosowanych w we wzorach obu metod. W przypadku metody nominalnej sztywności wprowadzone jest ograniczenie dotyczące maksymalnej wartości $K_{c}$ - wzór (4). Powoduje ono, że dla odpowiednio dużych wartości $n_{E d}$ począwszy od $\lambda=40$ przestaje ona rosnąć i przyjmuje stałą wartość. Gdyby nie było tego ograniczenia różnice pomiędzy wynikami byłyby mniejsze.

$\mathrm{Z}$ drugiej strony w metodzie nominalnej krzywizny występuje współczynnik $\frac{n_{u}-n_{E d}}{n_{u}-n_{b a l}} \leq 1$ korygujący początkową wartość krzywizny. Ze wzrostem wartości siły $n_{E d}$ ponad $n_{b a l}$ uwzględnia się zmniejszenie początkowej krzywizny. Jest to zgodne z rzeczywistością, gdyż im większa część przekroju staje się ściskana tym krzywizna staje się mniejsza.

Te dwa przeciwstawnie działające współczynniki są podstawowym źródłem różnic w wynikach. 
Tabela 1. Porównanie przyrostów wartości momentów obliczonych zgodnie z metodą nominalnej sztywności (N. Sz.) oraz nominalnej krzywizny (N. K.) dla stopnia zbrojenia równego $1 \%$

Table 1. Comparison of bending moment increments calculated according to the nominal stiffness method (N. Sz.) and the nominal curvature method (N. K.) for steel percentage $1 \%$

\begin{tabular}{|c|c|c|c|c|c|c|c|c|c|}
\hline \multirow{3}{*}{$n_{E d}$} & \multicolumn{3}{|c|}{$\lambda=30$} & \multicolumn{3}{|c|}{$\lambda=50$} & \multicolumn{3}{|c|}{$\lambda=60$} \\
\hline & N.Sz. & N. K & \multirow{2}{*}{ różnica } & N.Sz. & N. K & \multirow{2}{*}{ różnica } & N.Sz. & N.K & \multirow{2}{*}{ różnica } \\
\hline & \multicolumn{2}{|c|}{$m_{E d}$} & & \multicolumn{2}{|c|}{$m_{E d}$} & & \multicolumn{2}{|c|}{$m_{E d}$} & \\
\hline 0.215 & 0.295 & 0.290 & $2 \%$ & 0.308 & 0.300 & $3 \%$ & 0.348 & 0.329 & $6 \%$ \\
\hline 0.243 & 0.306 & 0.301 & $2 \%$ & 0.322 & 0.312 & $3 \%$ & 0.368 & 0.345 & $7 \%$ \\
\hline 0.283 & 0.322 & 0.314 & $2 \%$ & 0.340 & 0.328 & $4 \%$ & 0.395 & 0.366 & $8 \%$ \\
\hline 0.364 & 0.347 & 0.337 & $3 \%$ & 0.371 & 0.354 & $5 \%$ & 0.444 & 0.403 & $10 \%$ \\
\hline 0.405 & 0.357 & 0.345 & $3 \%$ & 0.383 & 0.364 & $5 \%$ & 0.465 & 0.419 & $11 \%$ \\
\hline 0.486 & 0.371 & 0.358 & $4 \%$ & 0.402 & 0.381 & $6 \%$ & 0.500 & 0.446 & $12 \%$ \\
\hline 0.499 & 0.372 & 0.359 & $4 \%$ & 0.405 & 0.383 & $6 \%$ & 0.505 & 0.450 & $12 \%$ \\
\hline 0.553 & 0.363 & 0.349 & $4 \%$ & 0.397 & 0.374 & $6 \%$ & 0.501 & 0.444 & $13 \%$ \\
\hline 0.630 & 0.348 & 0.334 & $4 \%$ & 0.383 & 0.360 & $7 \%$ & 0.509 & 0.433 & $18 \%$ \\
\hline 0.701 & 0.334 & 0.318 & $5 \%$ & 0.369 & 0.345 & $7 \%$ & 0.519 & 0.419 & $24 \%$ \\
\hline 0.833 & 0.301 & 0.285 & $6 \%$ & 0.337 & 0.311 & $8 \%$ & 0.535 & 0.385 & $39 \%$ \\
\hline 0.895 & 0.284 & 0.268 & $6 \%$ & 0.321 & 0.293 & $10 \%$ & 0.539 & 0.364 & $48 \%$ \\
\hline 1.012 & 0.244 & 0.229 & $7 \%$ & 0.285 & 0.251 & $13 \%$ & 0.537 & 0.315 & $70 \%$ \\
\hline 1.123 & 0.198 & 0.185 & $7 \%$ & 0.239 & 0.204 & $17 \%$ & 0.513 & 0.258 & $99 \%$ \\
\hline
\end{tabular}

Analogiczne obliczenia przeprowadzono dla przekrojów, które są zbrojone symetrycznie a ich stopień zbrojenia wynosi $\rho_{1}=\rho_{2}=0.25 \%$. Wybrane wyniki przedstawiono $w$ tab. 2. Ogólny wniosek jest tożsamy z wcześniej sformułowanym - zastosowanie metody nominalnej sztywności prowadzi do wyników większych niż te, które otrzymuje się korzystając z metody nominalnej krzywi-

Tabela 2. Porównanie przyrostów wartości momentów obliczonych zgodnie z metodą nominalnej sztywności (N. Sz.) oraz nominalnej krzywizny (N. K.) dla stopnia zbrojenia równego $0.25 \%$

Table 2. Comparison of bending moment increments calculated according to the nominal stiffness method (N. Sz.) and the nominal curvature method (N. K.) for steel percentage $0.25 \%$

\begin{tabular}{|c|c|c|c|c|c|c|}
\hline \multirow{2}{*}{$n_{E d}$} & \multicolumn{3}{|c|}{$\lambda=40$} & \multicolumn{3}{c|}{$\lambda=50$} \\
\cline { 2 - 3 } & $N . K$ & $N . S z$. & \multirow{2}{*}{ różnica } & N. K & N.Sz. & \multirow{2}{*}{ różnica } \\
\cline { 2 - 3 } \cline { 5 - 7 } & \multicolumn{2}{|c|}{$m_{E d}$} & & \multicolumn{2}{c|}{$m_{E d}$} & \\
\hline 0.098 & 0.104 & 0.111 & $6 \%$ & 0.110 & 0.120 & $9 \%$ \\
\hline 0.131 & 0.122 & 0.132 & $9 \%$ & 0.129 & 0.145 & $13 \%$ \\
\hline 0.214 & 0.161 & 0.183 & $14 \%$ & 0.173 & 0.207 & $20 \%$ \\
\hline 0.283 & 0.189 & 0.220 & $17 \%$ & 0.205 & 0.253 & $24 \%$ \\
\hline 0.533 & 0.241 & 0.288 & $20 \%$ & 0.269 & 0.342 & $27 \%$ \\
\hline 0.678 & 0.223 & 0.271 & $22 \%$ & 0.251 & 0.325 & $29 \%$ \\
\hline 0.770 & 0.202 & 0.248 & $23 \%$ & 0.228 & 0.326 & $43 \%$ \\
\hline 0.815 & 0.188 & 0.232 & $23 \%$ & 0.213 & 0.322 & $51 \%$ \\
\hline 0.949 & 0.135 & 0.176 & $30 \%$ & 0.154 & 0.277 & $80 \%$ \\
\hline
\end{tabular}


zny. Warto zwrócić uwagę, że znaczące różnice występują tu wcześniej, tzn. przy mniejszych wartościach $n_{E d}$. Wynika to z tego, że w metodzie nominalnej sztywności rola zbrojenia jest istotniejsza. Struktura wzoru określającego nominalną sztywność jest tak skonstruowana, że wpływ betonu jest mocno ograniczony wartością współczynnika $K_{c}$.

\subsection{Obciążenia długotrwałe}

Sposób uwzględnienia wpływu pełzania w obu metodach jest różny. W metodzie nominalnej sztywności jest on uwzględniony przez współczynnik $K_{c}$. Jego forma prowadzi do stwierdzenia, że spadek sztywności wywołany pełzaniem jest równy stosunkowi $\frac{1}{1+\varphi_{e f}}$. Przekłada się to na zmniejszenie wartości

siły $N_{b}$ a tym samym na przyrost wartości momentu drugiego rzędu. W metodzie nominalnej krzywizny uwzględnienie pełzania jest wyrażone przez zastosowanie współczynnika w postaci $\left[1+\varphi_{e f}\left(0.35+\frac{f_{c k}}{200}-\frac{\lambda}{150}\right)\right]$.

$\mathrm{Na}$ rys. 4. przedstawiono wybrane rezultaty obliczeń. Linie ciągłe odpowiadają wynikom otrzymanym $\mathrm{z}$ metody nominalnej krzywizny dla $\lambda=40$ odpowiednio dla obciążeń doraźnych i odpowiadających $\varphi_{\text {ef }}=1.2$. W odniesieniu do metody nominalnej sztywności zastosowano linie przerywane. Grubą linią zaznaczona jest krzywa graniczna. Bez wnikania w szczegóły można stwierdzić, że

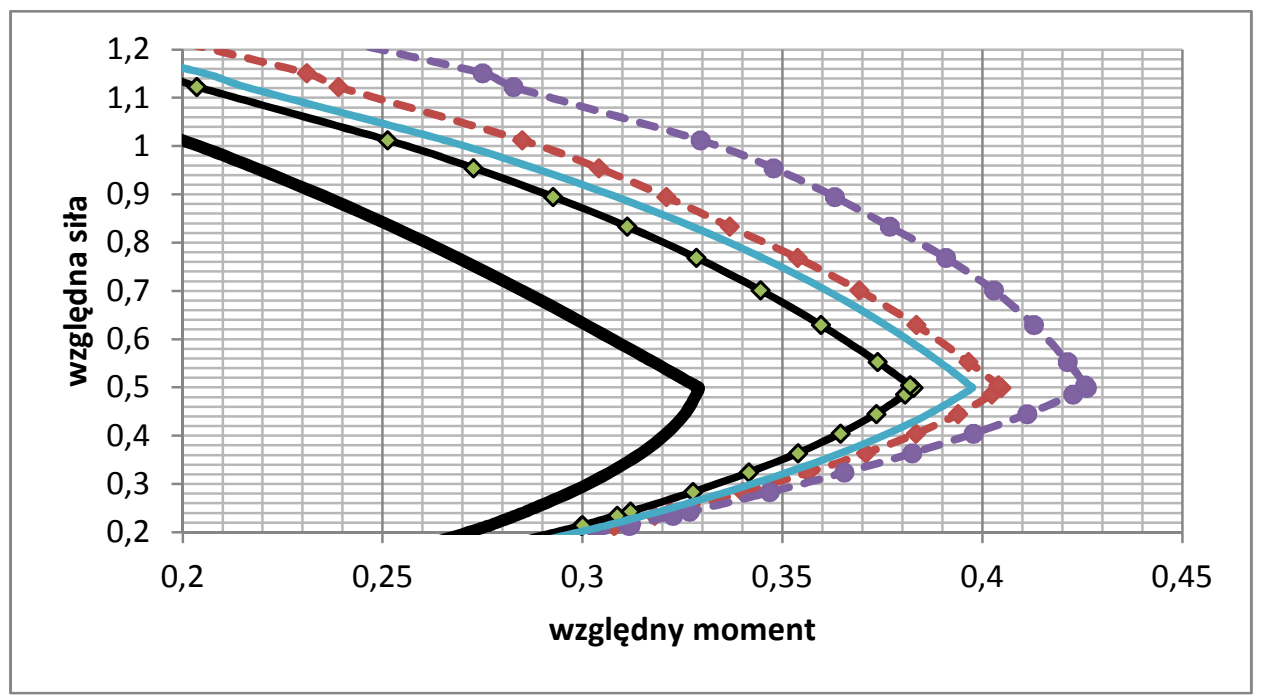

Rys. 4. Zmiany wartości momentów w funkcji smukłości

Fig. 4. Changes of bending moment due to slenderness 
uwzględnienie pełzania zwiększa jeszcze różnice pomiędzy wynikami otrzymywanymi z tych metod. Spowodowane jest to różnicą pomiędzy zastosowanymi w tym celu współczynnikom (korzystny wpływ uwzględnienia smukłości).

\section{Uwagi końcowe i wnioski}

W pracy przedstawiono porównania wyników obliczeń momentów zginających wykonanych dwoma przybliżonymi metodami, które są zamieszczone w obowiązującej normie. $\mathrm{Z}$ formalnego punktu widzenia projektant, obliczając wydzielone słupy, może korzystać z dowolnej z nich. Nie byłoby problemów, gdyby otrzymywane w ten sposób wyniki niewiele się od siebie różniły.

W celu pełniejszej analizy wyników otrzymanych z wykorzystaniem obu metod za podstawę wykorzystano krzywe graniczne (interakcji) w funkcji bezwymiarowych parametrów $m_{E d}=n_{E d} e / d$ oraz $n_{E d}$. Dzięki temu można zilustrować, dla założonych parametrów materiałowych i różnych stopni zbrojenia, wartości przyrostu momentu dla dowolnych wartości $n_{E d}$. Główną zmienną staje się wtedy wartość smukłości $\lambda$. W celu osiągnięcia bardziej przejrzystych wyników obliczenia wykonano osobno dla obciążeń doraźnych i długotrwałych.

Można wtedy zauważyć, że dobra zgodność wyników uzyskanych z obu metod ma miejsce wtedy, gdy wartości $n_{E d}<n_{b a l}$ a przy tym smukłości nie przekraczają wartości rzędu 50. Podstawowe źródło różnic (większe wartości otrzymywane z metod nominalnej sztywności) sprowadza się do czysto empirycznej postaci współczynnika $K_{c}$, który określa udział betonu w wartości nominalnej sztywności.

Jest on ograniczony do maksymalnej wartości równej $K_{c} \leq \sqrt{\frac{f_{c k}}{20}} \frac{0.2}{1+\varphi_{e f}}$. Oznacza to, że dla dużych wartości $n_{E d}$, gdy większość przekroju jest ściskana nie uwzględnia się zwiększenia sztywności. Jest to mocno konserwatywne podejście i można znaleźć w literaturze inne rozwiązania bardziej „optymistyczne” np. [6]. W rzeczywistości wzrost wartości siły, którą może przenieść słup $n_{R d}$ wynika z faktu, że jego strefa ściskana, a więc nie podlegająca zarysowaniu, ulega zwiększeniu. Idealnie osiowo ściskany słup nie ma żadnej krzywizny.

Na tym właśnie założeniu skonstruowany jest w metodzie nominalnej krzywizny współczynnik $\frac{n_{u}-n_{E d}}{n_{u}-n_{b a l}} \leq 1$. Użycie go jest równoznaczne z założeniem, że krzywizna zmienia się liniowo od maksymalnej - dla sytuacji, gdy $n_{E d}=n_{b a l}$ do zera przy $n_{E d}=n_{u}$, czyli gdy $m_{E d}$ maleje od wartości maksymalnej do zera. Użycie tego współczynnika jest określane w MC2010 jako obliczenia na drugim (dokładniejszym) poziomie. Z drugiej strony są prace [7], które wskazują, że celowe może być przyjmowanie większej wartości początkowej krzywizny dla $n_{E d}=n_{b a l}$. Zamiast przyjmować do obliczeń wartości odkształceń w stali sugerują, że lep- 
szym rozwiązaniem jest oparcie wyliczenia krzywizny na podstawie odkształceń w betonie, które mogą być większe - 3.5\%o. To prowadziłoby do przyrostu wartości mimośrodów drugiego rzędu.

Konkludując można stwierdzić, że pomimo tego, iż metoda nominalnej sztywności ma „lepsze” podstawy teoretyczne, to należy raczej rekomendować projektantom korzystanie z metody nominalnej krzywizny.

Ograniczenie stosowania do przekrojów symetrycznie zbrojonych można pominąć. Ma ono w istocie znaczenie, przy wyznaczaniu krzywizny dla $n_{E d}=n_{b a l}$. Po przekroczeniu tej wartości siły rolę zaczyna pełnić omawiany już współczynnik korygujący krzywiznę.

\section{Literatura}

[1] PN-EN 1992-1-1 Projektowanie konstrukcji z betonu. Część 1-1: Reguły ogólne i reguły dla budynków. PKN, Warszawa 2008.

[2] fib Bulletin 56: Model Code 2010.

[3] Sekcja Konstrukcji Betonowych KILiW PAN: Podstawy projektowania konstrukcji żelbetowych i sprężonych według Eurokodu 2. Dolnośląskie Wydawnictwo Edukacyjne, Wrocław 2006.

[4] CEB/FIP manual of Buckling and instability, The Construction Press, London 1978.

[5] Pędziwiatr J.: Wybrane problemy dotyczące analizy efektów II rzędu w odniesieniu do słupów wydzielonych, 55 Konferencja Naukowa KILiW PAN i KN PZITB, Krynica 2009, str. 257-264.

[6] Bonet J., Romero M., Miguel P.: Effective flexural stiffness of slender reinforced concrete columns under axial forces and biaxial bending. Engineering Structures 2011, str. 881-893.

[7] Barros H., Silva V., Ferreira C.: Second order effects in slender concrete columns reformulation of the Eurocode 2 method based on nominal curvature. Engineering Structures 2010, str. 3989-3993.

\section{THE METHODS FOR CALCULATIONS OF SECONDARY EFFECTS - REMARKS AND COMPARISONS}

\section{S u m m a r y}

It is necessary to take into account the secondary effects during dimensioning of slender columns. It means that forces in a structure must by increased by values caused by its displacements. In practice it leads to calculations of additional bending moment or eccentricity. There are three methods in the code and an engineer must choose one of them and be able to check the results. In this paper these methods were generally described and compared. It is possible to state that the use of the nominal stiffness methods leads to significantly higher results for additional moments. It is particularly valid for high values of slenderness and of relative axial forces. Similar conclusions may be drawn when influence of creep is taken into account.

Keywords: secondary order effects, nominal curvature, nominal stiffness, general method, results comparisons

Przestano do redakcji: $15.06 .2017 \mathrm{r}$.

Przyjęto do druku: 01.09.2017 r. 